\title{
Recent debates regarding the restoration of modern architecture in Italy
}

Ana Carolina de Souza Bierrenbach

Ana Carolina de Souza Bierrenbach é Doutora em Arquitetura e Urbanismo; Professora da FAUFBA e do PPGAU-UFBA; linabiba@ yahoo.com

\begin{abstract}
This article presents the recent debates on the restoration of modern architecture in Italy, focusing on the contributions of some of the most important theoreticians of the country. It points out the understandings of the term "modern architecture" and points out the existence of four restoration tendencies, examining its foundations: 1) The restoration of concepts - DOCOMOMO-International and DOCOMOMO-Italy; 2) The restoration of meanings - Paulo Marconi; 3) The restoration of the materials - Amedeo Bellini, Marco Dezzi Bardeschi and Paolo Torsello; 4) The restoration of materials and images: Giovanni Carbonara.
\end{abstract}

Keywords: Theories of restoration, modern architecture, Italy.

\section{Resumo}

Este artigo apresenta os debates recentes sobre o restauro da arquitetura moderna na Itália, concentrando-se nas contribuições de alguns dos teóricos mais importantes do país. Assinala os entendimentos sobre o termo "arquitetura moderna" e aponta a existência de quatro tendências de restauro, examinando seus fundamentos e apontando seus principais teóricos: 1) O restauro dos conceitos - DOCOMOMO-Internacional e DOCOMOMO-Itália; 2) O restauro dos significados - Paulo Marconi; 3) O restauro das matérias - Amedeo Bellini, Marco Dezzi Bardeschi e Paolo Torsello; 4) O restauro das matérias e das imagens: Giovanni Carbonara.

Palavras-chave: teorias de restauro, arquitetura moderna, Itália.

\section{Resumen}

Este artículo presenta los recientes debates sobre la restauración de la arquitectura moderna en Italia, centrándose en las contribuciones de algunos de los teóricos más importantes del país. Toma nota de los entendimientos del término "arquitectura moderna" y señala la existencia de cuatro tendencias de restauración, examinando sus fundamentos y apuntando sus principales teóricos: 1) La restauración de los conceptos - DOCOMOMO-Internacional y DOCOMOMO-Italia; 2) La restauración de los significados - Paolo Marconi; 3) La restauración de los materiales - Amedeo Bellini, Marco Dezzi Bardeschi y Paolo Torsello; 4) La restauración de los materiales e imágenes: Giovanni Carbonara.

Palabras-clave: Teoría de la restauración, arquitectura moderna, Italia.

\section{Introduction}

$\mathbf{T}$ his article examines recent debates regarding the restoration of modern architecture in Italy, concentrating on the contributions made by some of the country's principal theorists, including Amedeo Bellini, Marco Dezzi Bardeschi, Giovanni Carbonara, Paolo Mar- 
coni and Paolo Torsello. The positions of DOCOMOMO International and DOCOMOMO Italy are also central to this text. ${ }^{1}$

When addressing this topic, we should first note that no consensus exists about the notions of "modern architecture" or "restoration".

Other expressions, as well as "modern architecture," are also used, such as "new architecture", "the architecture of the nineteen hundreds", "functional architecture" or "contemporary architecture", while some authors use more than one term. The expression "Modern Movement" is very frequently used, although it provides a more restricted profile than the others, which has led some authors to question it as limiting a more complete understanding of 20th century architecture. ${ }^{2}$

Other authors note that "modern architecture" (with all its different names and nuances) usually contains features that differentiate it from traditional architecture: a rupture from preceding architectural norms and pre-determined types; the specificities of their methods of design and production, which apply to the notion of rationality; the search for experimentation in techniques and materials using mass production and prefabrication; the intention to more directly relate form with function, so that certain buildings take on precise functional features, which directly link them to formal solutions; while in other situations, there are functional options which are more open to changes that do not have a direct relationship with formal solutions, but which adopt a more rigorous geometry; the idea that once functionality, its materials and/ or techniques become obsolete, architecture could be replaced; the introduction of the concept of abstraction in architecture, with a predominance of the use of pure forms and colours; and modifications to the spatial concept, creating unusual interactions between the environment's internal and external dimensions. ${ }^{3}$

In practice, however, these rationalizations and experiments encounter a number of production difficulties; architects have problems applying material and technical innovations, so that they persistently use them inappropriately or continue to use traditional solutions with updated features; thus, in many cases, industrialized solutions themselves are seen to be more ideal than real. Although some modern architects maintain the notion that their projects should be replaced when their use has come to an end, others are aware that in practice this may not happen, asserting that their buildings must have the capacity to admit a change
1 We do not intend to conduct a historical overview of the debates that took place until the mid-20th century, or to cite authors such as Cesare Brandi, Renato Bonelli or Roberto Pane. Neither do we intend to discuss the positions of all those authors who have addressed this theme since the end of the last century, despite the wide-ranging debates in Italy. Instead, we prefer to centre our text on theoretical aspects, and leave debates that connect theory with practice for another time.

2 CASCIATO, 1999, p. 28; CASCIATO, 2007. p.39; GIOENI, p.127138. See: LA REGINA, 2007, p.67.

3 BELLINI, 1994, p.18-19. See: ARTIOLI, 1993，p.44; BELFIORE, 2012, p.33; BORIANI, 2003，p.10; DENTI, 1994, p.24; SALVO, 2016, p.15-16; SCIASCIA, 2007, p.54-55. 
4 GIOENI, 2004, p.248. See: ANZIVINO, 1994, p.97-98; BORIANI, 1994, p.90; BORIANI, 2003;

5 See: BORSI, 1994; CIUCCI, 2012, p.20; LA REGINA, 2007; MORABITO, 1993, p.145; PORZIO, 1993.

6 See: AVETA, 2002; MANGONI, 2012, p.103; MARINO, 2012.

7 See: BORIANI, 2003

8 DEZZI BARDESCHI, 1993, p. 136; See: BORIANI, 2003.

9 CARUGHI, 2017. of use. Some architects continue to believe that architecture has to endure, assuming an aspect of monumentality, something that frequently occurs in modern Italian architecture. Another issue is that precarious economic conditions and the absence of social consensus ultimately make it impossible for architecture supposedly intended to disappear to really be replaced. ${ }^{4}$

Although the term "restoration" is constantly seen in the debates we investigated, other themes appear that complement and explain it, linking intricate conceptions. ${ }^{5}$ The restoration of modern architecture is based on a discussion about the existence ${ }^{6}$ or inexistence of specificity in its method, in which the former is defended by the presence of one or more of the above-mentioned features.

Some theorists observe that, although modern architecture in fact contains certain specific features that have to be taken into consideration when working on it, this does not necessarily lead to a specific restoration method. ${ }^{7}$ One of these features is the constant use of experimental materials and techniques which rapidly deteriorate and are not usually maintained appropriately. It has been suggested that restorers are not adequately prepared to address these issues, although such difficulties can be overcome with research and professional training. Another aspect is the existence of standardized modern buildings and bulk standards that face resistance from current users, who tend to transform them to meet their needs, breaking away from their abstract features and incorporating more personalized elements, usually containing traditional aspects. ${ }^{8}$ There is also a greater public acceptance of the values and signs of deterioration in historical architecture, which does not occur with the modern. Critics also have greater difficulty in recognizing the values of more recent architecture: it is alleged that there is no consistent temporal distancing for the formulation of a relevant critical evaluation, as has been discussed by many, but this is still supported by Italian legislation (Law 42/2004) which asserts that a building can only be protected 50 years following construction, in the case of privately owned buildings, while the figure is 70 years for those that are publicly owned ${ }^{9}$.

We present some concepts below referring to the restoration of modern architecture, which have been addressed in recent Italian debates. The text seeks to join different positions together, summarizing their main arguments and highlighting whether or not they suggest the existence of specificity in relation to modern architecture restoration. 


\section{The restoration of concepts}

Certain theorists maintain that modern architecture manifests specific ${ }^{10}$ features that enable its concepts to be restored. Several of these theorists are linked to the DOCOMOMO network. ${ }^{11}$

The possibility of restoring concepts is based on discussions about authenticity. For these theorists, authenticity is mainly based on concepts, on the fundamental ideas of the architecture and the design, which have to be restored in order to guarantee full architectural continuity. ${ }^{12}$

In order to restore these concepts, it is important to track them back to their primary source, which is where the author's ideas are established. Authenticity may principally be found in the original design. In this since, they consider that the drawings contain precise information about the original design and must be restored with minimum transformation. ${ }^{13}$ Under certain circumstances, they also note the importance of data arising from the original material, asserting that this can point to the building's conceptions. ${ }^{14}$ Under other circumstances, the author's opinion is considered a point for consideration. ${ }^{15}$

Based on the reference work and these authentic documents, the authors therefore maintain that making copies of pieces, parts, or entire buildings, is completely valid; they do not consider that this constitutes a false history. ${ }^{16}$

This issue is related to the application of industrial and serialization production. For some of these theorists, the concept of modern architecture is related to the use of serial pieces and parts, often undertaken with minimal resources, assuming an experimental nature, and intended to be transitory. Thus, they consider it conceptually valid to use such parts to replace obsolete elements. They understand that they can change these for other, similar, ones, which have yet to be produced, in order to restore certain production elements and overcome their preliminary defects, or, should these solutions no longer be possible, replace them with others. They therefore believe that they can adequately improve the functionality of buildings by correcting errors. This replacement will not affect the building's authenticity, since it resides in the concept, rather than the material. ${ }^{17}$

Another aspect relates to the concept of abstraction, which is a feature of modern architecture. This
10 CASCIATO, 2017; PORETTI, 2012, p. 89; DE JONGE, 1993, p. 314.

11 Docomomo International (the International Working Party for the Documentation and Conservation of the Buildings, Sites and Neighbourhoods of the Modern Movement) is a non-governmental organization founded in 1988 in Holland, which has since expanded to include representations in a number of other countries, including Italy. DOCOMOMO Italy was set up in 1995 . The members of the Italian group describe their sphere of operation as the modern Italian architecture of the nineteen hundreds, which maintains specific features and is not precisely linked to the Modern Movement. According to Carughi, DOCOMOMO Italy aims to protect the architecture of the nineteen hundreds, in line with the international organization, and there is a theoretical affinity between the institutions (PORETTI, 1999; CARUGHI, 2017), although it is possible to note differences in attitude. This article seeks to describe, along general lines, both DOCOMOMO International's and DOCOMOMO Italy's understanding of restoration, particularly based on the positions of professionals who have played an important role in the institution, such as Maristella Casciato (1950), Rosalia Vittorini (1956), Sergio Poretti (1944) and Ugo Carughi (1948). Since Wessel De Jonge (1957), who is Dutch, is mentioned throughout the Italian discussions, his opinions have also been taken into consideration.

12 CASCIATO, 2007, p. 39-40. CASCIATO, 2008, p. xiii; DE JONGE, 1993. See: CANZIANI, 2003, p.108; 13 DE JONGE, 1993, p.156 e p.162. 14 PORETTI, 2012, p.90; VITTORINI, 2013.

15 DE JONGE, 1993, p.314.

16 VITTORINI, 2013. See: MORABITO, 1993, p.150.

17 PORETTI, apud SALVO, 2016, p.25-26; VITTORINI, 2013. Ver: BELFIORE， 2012， p.33; BELLINI, 1994, p.19; CAPOMOLLA, 2003, p.185-186; CASSANI, 2003， p.2324; CIUCCI, 2012, p.13; DE JONGE, 1993, p.145-146; LA REGINA, 2007; MORABITO, 1993, p.149150; SALVO, 2007, p.460; SALVO, 2007-2008; SALVO. 2016, p.87. 
18 See: BELLINI, 1994, p;20; BORIANI, 2003, p.7; BORSI, 1994, p.7; LOCATELLI, 2009, p.142; DELL'ERBA, 1999, p.404; SALVO, 2016, p.16-17 e 21

19 In "The modern culture of monuments", (1903) Alois Riegl outlines the values that guide the conservation of monuments, including novelty or antiquity. The former corresponds to the complete and perfect aspect of a work; the latter to the decay and imperfection the work acquires over time. It is more difficult for modern works to achieve this value, since they are more recent and have not had sufficient time to become established. See: CASSANI, 2003; DELL'ERBA, 1999, p.404; MARINO, 2007, p, 447-448; MARINO, 2012, p.112-114; SCARROCCHIA, 1994, p.25-26.

20 See: CASSANI, 2003, p.25; MARINO, 2007, p.447-448; SALVO, 2016, p.26-27.

21 See: BORSI, 1994, p.7; CASSANI, 2003, p.30; CORNOLDI, 2007, p.262; SALVO, 2016, p26-27.

22 CASCIATO, 2007, p. 39; PORETTI, 2012, p.90; DE JONGE, 1999, p.15.

23 CARUGHI, 2012, p.44; CASCIATO, 2007, p.xiii; DE JONGE, 1993, p.156. breaks from pre-existing frames of reference and often adopts pure volumes, compact forms, perfect surfaces and homogenous colours which, contrary to the techniques and materials related to function, have to endure over time. It is essential to transmit the integrity of the image. They assert that modern architecture is a finished art work which cannot be altered, but may be reconstituted. ${ }^{18}$

This idea is related to the value of novelty, which begins to prevail during modernity, in counterpoint to the value of antiquity. ${ }^{19}$ It recognizes that modern architecture is primarily designed to reflect the value of novelty, rejecting the value of antiquity. Theorists from this line of thought therefore assume that this value predominates, driving modern architecture to always appear new, rejecting an image of deterioration or ruin. 20

The configuration of images is related to the dissemination of modern architecture. Perfect images have been disseminated through books and journals and these tend to be configured as "real". The use of photographs $^{21}$ is fundamental to the propagation of images of recently constructed modern buildings, with little space given over to their users and their transformative activities, without the natural deterioration caused by time. Such photographs are taken as authentic documents which contribute to the repristination of the image at time zero.

Since it is understood that the original design, which maintains the image's most essential and perfect dimensions, have to predominate, any part or piece considered to be out of the ordinary may be removed and any additions have to maintain the features of the original images, without any differentiations that suggest their actuality, shaped as "invisible designs" (PORETTI, 2012, p. 94). New creations, do not therefore have the right to their own or current expression.

For these theorists, is it necessary to first value these buildings, indicating their artistic, historical, social and economic meanings. The greater the value detected in the building, the greater the attention that should be paid to the restoration of its fundamental design. ${ }^{22}$

These authors only accept limited changes related to the value of use, that is changes made by users to adapt buildings to their needs; this is particularly true of more iconic buildings. However, given that the concept of functionality is essential ${ }^{23}$, they consider it fundamental that these buildings continue to satisfy 
their users' current needs, at times allowing changes to spatial distribution, at others the incorporation of new facilities. This understanding means that they allow transformations that depart from a building's pre-existing use, not repairing its pieces and parts, but rather replacing them with other, more efficient, ones. Although reuse with functional adaptations is considered important, it is generally understood that the primary form should not be affected, still less that iconic buildings should fall into a state of ruin. ${ }^{24}$ Carughi, for his part, states that function can transform, which can affect form, provided it does not involve the loss of character. ${ }^{25}$

The reconstruction of buildings is considered fully realizable. This principally refers to architecture that has a manifest character. The fact that this addresses models whose initial goal is serial productions, which can be assembled, disassembled, reassembled and even displaced, leads these authors to understand that such reconstructions are pertinent, taking on a didactic and touristic function. 26

In view of this, the theorists suggest various options for restoration which depend on determining the values initially detected. DOCOMOMO International outlines the models for the principal restoration activities: restoration operating as a complete repristination; a repristination that introduces technical improvements, even if these are imperceptible; modifications carried out using current materials and techniques; or, finally, restructuring aimed at reuse, without paying a great deal of attention to historical or architectural values. To this end, it suggests the possibility of redefining and redesigning whole parts of buildings, based on the above-mentioned original designs, and/or on an examination of their constitutive features. ${ }^{27}$

Although the conservation of materials may take place, DOCOMOMO does not, in fact, see it as essential, since it is considered contrary to the provisional nature of the original concept of the Modern Movement. ${ }^{28}$

\section{The restoration of meanings}

Paolo Marconi (1933-2013) understands that there is no difference between the restoration of historical architecture and that of modern architecture. Any considerations made for the former are therefore also useful for the latter. We should remember that this theorist also manifests a certain contempt for modern architecture. ${ }^{29}$
24 CARUGHI, 2017. Ver: CASSANI, 2003; CAPOMOLLA, 2003, p.185186; DELL'ERBA, 1999, p.404.

25 CARUGHI, 2012, p.45.

26 See: CIUCCI, 2012, p.18; LA REGINA, 2007, p.73.

27 PORETTI, 2012, p. 89; VITTORINI, 2013, s/p. Ver: GIOENI, 2004, p.143; MORABITO, 1993， p.150; SALVO, 2016, p.40-41.

28 DE JONGE, 1993, p.155. See: BORIANI, 2003, p.18; CASSINI, 2003, p. 23.

29 GIMMA, 1993, p. 304; MARCONI, 1999, p.165; MARCONI, 2008, p. 152. 
30 MARCONI, 1999, p. 3-4, TORSELLO, 2005, p.47. MARCONI, 1999, p. 3-4, TORSELLO, 2005, p.47.

31 GIMMA 1993, p.301, MARCONI, 1999, p. X; TORSELLO, 2005, p.4546, MARCONI, 2008, p.151. See: BARDELLI, 1999, p.396.

32 MARCONI, 1999, p.IX, p.103, p.122, p.151; GIMMA, 1993, p. 122.

33 MARCONI, 1999, p.3.

34 GIMMA, 1993, p.301; MARCONI, 1999, p.28; TORSELLO, 2005, p.4546.
Marconi discusses the notion of authenticity: he thinks it may have meaning for works of art, but not for works of architecture. For him, authenticity is a "terrorist myth", which paralyses the restorer's operations, making it impossible to identify a building's main semantic characteristics so as to retrieve them. He believes that a certain amount of inauthenticity may even reinforce the meaning of a work. ${ }^{30}$

This theorist is not interested in determining which concepts guide a building's production. He considers that its main features may be found in any one of its phases of existence, as long as significant interventions are located within them. Nevertheless, he thinks that when the original designs still exist, as is frequently the case in modern architecture, they may provide a solid basis for restoration, based on an accurate philological study. In this sense, Marconi considers that the original drawings are a source which may lead to the faithful recovery of design features. ${ }^{31}$

If authenticity does not make sense, then copies do. He states that the replacement of a building's pieces and parts is entirely plausible. He calls these duplicates, asserting that the intention is not to reproduce only the image, but also the drawings, the materials, the techniques and the manufacturing conditions for these elements. He thinks that current users and the tourist masses are barely able to notice the difference between a well-made duplication and a poorly made one. ${ }^{32}$

This theorist thinks that modern architectural production, which is of an industrial and serialized nature, is based on the notion of repetition, moving away from an understanding that there are buildings - with their pieces and parts - that must be considered rare and unique. This further allows for their replacement with other similar buildings, and reaffirms the importance of copies. 33

When an assessment is made that the abstract features of a building, with their pure forms and surfaces, and their linked spaces, are those that represent the most significant phases of its trajectory, its semantic unity must be re-established, which involves recovering its characteristic image. ${ }^{34}$

In terms of the value of antiquity, Marconi suggests that the signs of the passing of time that cause the material to decay should not be entirely preserved, maintaining buildings "as if they were fossils" (MARCONI, 1999, p. 7). However, this does not mean that the value of novelty should prevail. Restorations con- 
ducted through repristination and duplication immediately assume an inconveniently gaudy aspect, which does not endure. New interventions age quickly, losing their novelty and reintegrating into the rest of the building. New architecture, on the other hand, including the modern, with its pure forms, which cause ruptures to the historical fabric that has been constituted over centuries, are seen as intrusions, that should not have the right to exist, since they break with the formal configurations of significant buildings. ${ }^{35}$

For this author, photographs must be used parsimoniously. This is one document that exists, but not the only one, nor a priority. One should ask which photograph to use - one of the building in its current state or one taken at some point in its past. He criticizes the way modern society replaces buildings with their photographic images. ${ }^{36}$

Marconi argues that restoration always involves an arbitrary selection of the elements to be inserted or extracted. It is possible to both remove the "spurious elements" and reintroduce significant elements through duplicates. For the author, when there is a need to insert new elements, they must follow drawings, materials and traditional procedures in such a way that they become unrecognized in the building, without causing a break from its linguistic unity. He therefore considers buildings to be unified art works that do not tolerate creations, neither those with innovative characteristics, nor those with few contrasting traits. He asserts that "the restorer's greatest prize must be that of the doctor: to return the patient to health without leaving any trace of their passing" (MARCONI, 1999, p.172). ${ }^{37}$ In other words, their role is not to create, but to repair. ${ }^{38}$

In order to select the building for restoration and determine the appropriate actions to be carried out, a preliminary valuation of its historical and artistic aspects is required. Both of these are important for Marconi, and a restoration only takes place when one can detect that the architecture is "beautiful, well-constructed and historically significant" (MARCONI, 2008, p.152). In his view, these values may be found in any one of the building's phases of existence. ${ }^{39}$

For this author, the value of use is limited. He asserts that the transformations that users enact on buildings may be tolerated, provided that they do not affect the features that confer its architectural meaning. However, he thinks that they should remain occupied, preferably for uses compatible with their original use, as long as the meaning is preserved. 40
35 MARCONI, 1999, p.X, p.4, p.28, p.31, p.148-149.

36 MARCONI, 2008, p. 151-153.

37 MARCONI, 1999, p.X, p.7, p.31; p.167. See: CORNOLDI, 2007, p. 263.

38 MARCONI, 1999, p.46.

39 MARCONI, 1999, p.4-6; MARCONI, 2008, p.153, TORSELLO, 2005, p.45-46.

40 MARCONI, 1999, p.7, p.125. 
41 MARCONI, 1999, p.62.

42 GIMMA, 1993, p. 301. See: BARDELLI, 1999, p.396.

43 MARCONI, 1999, p.X, p.4; MARCONI, 2008, p.153; TORSELLO, 2005, p.45, p.48. See: BARDELLI, 1999, p. 395.

44 BELLINI, 1994, p.20; BELLINI, 2008, p.145; GIOENI, 2004, p.86; LOCATELLI, 2009, p.51, p.68, p.92; TORSELLO, 2005, p.23. See: AVETA, 2012, p.41; BORIANI, 2003, p.16; CASSANI, 2003, p.29; CANZIANI, 2003, p.109-110.

45 DEZZI BARDESCHI, apud LOCATELLI, 2009, p.68.
In the case of the destruction of model buildings, including modern ones, the author permits reconstruction up to the smallest detail, "as it was and where it was". 41 This must be based on documents which allow for philological reconstitution. ${ }^{42}$

The restoration of a modern building must, therefore, reinstate its stability and durability, maintaining or re-establishing its messages, so as to ensure the transmission of the unity of its semantic character. For the theorist, it is possible to restore the building "as it was and where it was", authorizing repristination. More important than the conservation of the concepts, images or even the materials, is the need to conserve its meanings. ${ }^{43}$

\section{The Restoration of materials}

Theorists such as Amedeo Bellini (1940), Marco Dezzi Bardeschi (1934) and Paolo Torsello (1934) also understand that there is no specificity in the restoration of modern architecture, although they do recognize some of its specific characteristics. Their observations about the restoration of historical architecture can also be applied to modern architecture.

They establish the notion of authenticity. In this case, there is an understanding that authenticity is centred on the unique and original nature of materials accumulated over time and in the need for these to transmit, as completely as possible, all the building's features. For them, maintaining materials is the only way for the building's information to reach its current and future users, enabling the fruition, interrogation and full interpretation of the building. ${ }^{44}$

To sustain his thesis of authenticity, Dezzi Bardeschi cites Walter Benjamin: "authenticity is a thing that is the quintessence of all that is transmissible from its origin on, ranging from its physical duration to its historical testimony" (DEZZI BARDESCHI, in LOCATELLI, 2009, p.68). ${ }^{45}$

They assert that a building's authenticity cannot be defined from the selection of a point in its original or later history assumed to be more important than other points. They question theorists who assert that authenticity may be found in the concepts launched by the authors of designs. Neither do they believe that such ideas can be detected in the original designs, even when there are a great many records, as is often the case with modern buildings. They question which designs are the originals, arguing that architects make 
a series of drawings until they reach the solution that is finally used, and which even then may be transformed during construction or in use. Drawings may contain useful information, but are autonomous in relation to the constructed architecture, which has to be understood as the primary source. ${ }^{46}$

For these theorists, if the material is not authentically maintained, it becomes false. A copy of a building, including a modern one, does not manifest quintessence. In addition, falsification undermines any transmission of its features. ${ }^{47}$

In relation to the industrial and serialized production of the pieces and parts of modern buildings, they state that those that are damaged should not be replaced with similar ones. They consider that, even if the elements that constitute the building are still industrially produced, one cannot use them to replace those that previously existed, because the latter are authentic documents, while the former are not. This rejection of the replacement of elements with those produced in the present day is also justified by the fact that, in practice, many modern buildings might intend to use pieces and parts that can be produced industrially but do not do so, instead calling on traditional materials and techniques hidden under the mantle of modernity. ${ }^{48}$ Dezzi Bardeschi asserts that it is precisely because modern architecture uses fragile materials with accelerated cycles of degradation, that greater care should be taken to ensure their conservation. ${ }^{49}$

They understand that modern architecture is abstract in nature and possesses specific characteristics. They suggest that there is a tendency to consider that the image has to endure in perfect and idealized form, unaffected by the actions of time or of users. This tendency is contrary to the actual concepts of this architecture, which, according to Dezzi Bardeschi, does not need to create its own mythology as an object of worship. ${ }^{50}$ However, they reject the possibility that such an image can be restored to its original form, as if returning a lost unit. They advocate acceptance that the image will not be the same. They draw attention to the propagation of images by the Modern Movement, promoting monumental buildings with perfect features, making it difficult to accept any transformation. In this sense, they understand that modern architecture has to be considered as an open art work, whose original image should not be reconstituted; instead, space should be made for its careful revision, with a distinct view about what this means. ${ }^{51}$
46 BELLINI,1994, p. 20; BELLINI, 2008, p. 145; GIOENI, 2004, p.148, p.155. p.157, p.164; LOCATELLI, 2009, p. 51, p.164, p.192, p.194; TORSELLO, 2006, p.25-26; p.35, p.53; TORSELLO, 2008, p.4. See: ANZIVINO, 1994, p.97; BORIANI, 2003, p.17; CANZIANI, 2003, p.111-112.

47 BELLINI, 1994, p.20;

48 GIOENI, 2004, p.138-139; LOCATELLI, 2009, p.42. See: ANZIVINO, 1994, p.97.

49 GIMMA, 1993, p.106; LOCATELLI, 2009, p.262.

50 DEZZI BARDESCHI, 2012, p. 95.

51 BELLINI, 2008 p.145; BELLINI, 1994; GIOENI, 2004, p.162; LOCATELLI, 2009, p.192 e p.262; DEZZI BARDESCHI, 2012, p.95; TORSELLO, 2005, p. 54; TORSELLO, 2006, p.147 e 157. See: ANZIVINO, 1994; CASSIANI, 2003. 
52 DEZZI BARDESCHI, apud GIOENI, 2004, p. 170-171.

53 LOCATELLI, 2009, p.148.

54 BELLINI, 2008 p. 145; DEZZI BARDESCHI, 2008; GIOENI, 2004, p.144; LOCATELLI, 2009, p.192; TORSELLO, 2008, p.153-155. See: CARRERA, 2008; MANGONI, 2012, p. $102-103$.

55 BELLINI, 1994; BELLINI, 1997, p.18; GIOENI, 2004, p.139; LOCATELLI, 2009. p.27; TORSELLO, 1997, p.30; TORSELLO, 2003, p.3; TORSELLO, 2006, p.144 e 155. See: CANZIANI, 2003, p.111.

56 BELLINI, 1997, p.20

57 DEZZI BARDESCHI, apud GIOENI, 2009, p. 174.

58 LOCATELLI, 2009, p. 103.
This has an impact on their understanding of the relationship between the values of novelty and antiquity. This sees that the former is less important than the latter, since it considers that the material and the image may shed their new aspects in their entirety, in a demonstration of the effects of time. Thus, they state that modern buildings contain evidence of the marks of aging, although this supposedly contradicts the authors' aspirations to transmit new, permanent messages. Dezzi Bardeschi also believes that ruins have charm. ${ }^{52}$ By outlining this understanding, he reveals one significant aspect of modern architecture, which is the constant use of fragile and short-lived materials. ${ }^{53}$

For these theorists, the photographs that are continually published in the histories of modern architecture have a predominantly negative effect. They transform buildings into icons, which ultimately do not exist in the real world, but in an illusory one. This leads to the reproduction of an immutable image that does not deteriorate over time. This iconic aspect is reinforced when architects undertake pilgrimages to visit paradigmatic buildings, hoping to find them precisely as they know them from photographs. Photographs may be considered useful documents for an understanding of how the building changes over time, but cannot be transformed into a definitive guide for restoration. ${ }^{54}$

Since the historical aspects of the materials and techniques that shape these buildings have to be dominant, they assert that the pieces and parts inserted over all the stages of a building's life by different its users must not be removed or, should this occur, it only occur occasionally. ${ }^{55}$ Bellini asserts that the boundary between conservation and transformation emerges out of fundamental valuations. ${ }^{56}$ For his part, Dezzi Bardeschi is not entirely clear about where this boundary resides, asserting that "incongruence or vague installations" may be extracted (DEZZI BARDESCHI, in GIOENI, 2009, p. 174). ${ }^{57}$

They do not believe that a work has a pre-established historical or artistic dimension at one specific time and that it is therefore finished. This leads them to believe that new creations have the right to appear and coexist with historical ones. They criticise those interventions that intend to appear historical, even when they employ traditional materials and techniques. ${ }^{58}$ However, there are nuanced differences between the authors' positions. Bellini understands that, where necessary, one could consider, simultaneously and in a unified manner, well established past elements while 
adding other, clearly current, ones. ${ }^{59}$ Dezzi Bardeschi maintains the need to conserve, but also to insert new creations. Initially he asserts that these are two, separate operations, one related to conservation and the other to a new project. Later on, these terms alternate and the author asserts the need to make an expert alliance between these operations, summarized in the following formula: restoration $=$ conservation project + innovation project. ${ }^{60}$ Torsello suggests the need to work within the limits imposed by conservation, using careful concepts, and expert and reciprocal contaminations, which are fully up to date. ${ }^{61}$

For these theorists, it is not important whether or not the authors of projects defend permanency, changes or even the removal of their works. What matters is that the current consciousness considers that these works should be conserved. Using different arguments, Bellini, Dezzi Bardeschi and Torsello all assert that the determination of artistic and historical values is always partial and leads to limited understandings of building practices. As a consequence, ultimately, many restorers only provide restricted possibilities for activating interrogations, interpretations or fruitions. ${ }^{62}$

Regarding the value of use, they think it is necessary to retain the maximum possible changes made by users to adapt the building to their needs, even if this presupposes a distortion of its initial artistic features. In relation to current demands, they all consider that the recovery of functionality is important, even if it affects modern architecture's supposed concept of premeditated obsolescence. However, there are subtle differences in these authors' opinions. Bellini thinks that the value of use is equal to other values. For this theorist, it not acceptable to impose precarious living conditions on a building's users, although unnecessary changes should be avoided. ${ }^{63}$ Dezzi Bardeschi asserts the need to pay attention to the value of use, enabling functional recovery and the renovation of historical buildings with the maximum suitability and respect for its historically embedded features. ${ }^{64}$ Torsello thinks it is necessary to respond to the current needs of people who do not want to live in buildings that manifest signs of decay. ${ }^{65}$

Reconstruction is considered to limit the reproduction of symbolic buildings with no basis, without interfering in a pre-existing building or assuming a merely didactic nature. This is not related to restoration, nor even to something that takes place through the repristination of the features "as they were and where
59 BELLINI, 1997 p.19; GIOENI, 2004, p.138; TORSELLO, 2005.

60 LOCATELLI, 2009; TORSELLO, 2005, p.39.

61 TORSELLO, 1997, p.32-33; TORSELLO, 2006; TORSELLO, 2005, p.56.

62 BELLINI, 1994, p.20; BELLINI, 1997, p.20; BELLINI, 2004, p.30; DEZZI BARDESCHI，2012， p.96; DEZZI BARDESCHI, 2015, p.114; GIOENI, 2004, p.51-52; LOCATELLI, 1999, p. 23; TORSELLO, 1997, p.30-3; TORSELLO, 2003， p.9; TORSELLO, 2005; TORSELLO, 2006, p.132.

63 BELLINI, 1997, p.18; TORSELLO, 2005, p.23-24.

64 DEZZI BARDESCHI, 1993, p.108; GIOENI，2004; LOCATELLI， 2009; TORSELLO, 2005, p. 39.

65 TORSELLO, 2005, p. 53; TORSELLO, 2006, p. 144 e 158. 
66 BELLINI, 1994, p.20; GIOENI, 2004, p. 143 e 147; DEZZI BARDESCHI, 2012, p.95.

67 BELLINI, 1997, p; 20; LOCATELLI, 2009, p.47; TORSELLO, 2005; TORSELLO, 2006, p.99.

68 DEZZI BARDESCHI, apud GIOENI, 2009, p. 174.

69 LI, 2009; TORSELLO, 2005. See: BORIANI, 2003, p.9.

70 CARBONARA, 2006, p. 22-24.

71 CARBONARA, 1997, p.18; SALVO, 2016, p.33.

72 CARBONARA, 1997, p.588; CARBONARA, 2006, p. 24; CARBONARA, 2007-2008, p.12; CARBONARA, 2008, p.148. See: AVETA, 2012, p.38; SCIASCIA, 2007

73 CARBONARA, 2006, p. 24; CARBONARA, 2007-2008, p.11-14; CARBONARA, 2008, p. 148. Ver: SALVO, 2016, p.78. they were". ${ }^{66}$ Torsello complements this by asserting that reconstructions do not refer to the initial works, but rather to their recent authors, establishing few links with the original. ${ }^{67}$

For these authors, the notion of restoration, including of modern architecture, is related to an erroneous understanding of its scope, which needs to be overthrown and redefined. They consider it necessary to extrapolate from the restoration of concepts, meanings or image. ${ }^{68}$ There are subtle distinctions between their different understandings, but they all signal the need to conserve, to contain material decay, to control transformations in order to minimize the loss of signs and historic testimonies. These need to maintain their potential to transmit information and activate interpretations and fruitions. In all cases, they position themselves as strongly against the possibility of remaking works, as against repristination. ${ }^{69}$

\section{The restoration of materials and images}

Giovanni Carbonara (1942) and other theorists who represent this trend also suggest that the principles that guide the restoration of historical architecture are the same as those that guide modern architecture. ${ }^{70}$

Authenticity continues to be an essential notion, and may be found in the unique nature of the original material, which also incorporates the architectural image. This means ensuring that it is transmitted in such a way as to cause the least possible harm, in order for it to continue to enable the dissemination of information and the formulation of interrogations, interpretations and fruitions. ${ }^{71}$

In this case, there is another consideration - that authenticity is not recorded in the ideas that emerge from an author's original designs, but rather in the principal imagery and markings deposited in a building, given that it has been constructed over time, from its initiation to the present day. Criticism is also made of the indiscriminate use of original drawings as sources of privileged information for restoration, with arguments similar to those already made by other theorists. ${ }^{72}$

Once the original is lost and a copy is formed, authenticity is also lost. Carbonara asserts that, however scrupulously a copy is made, it is a mere interpretation and only provides a partial truth about the building. ${ }^{73}$ 
This understanding of copies has consequences for the characteristic mode of production in modernization, which occurs through industrial, sometimes serialized, production. In this case, the fact that modern architects have conceived their buildings so that their pieces and parts can be replaced by other, mass produced, ones, or that they have contemplated the notion that their buildings might be demolished, should they no longer respond to the demands of users, does not make sense. It is thought that even those pieces and parts that have been tested and then discarded should not be disposed of, at the cost of losing the work's historical and artistic content. For these authors, it is important to consider that most of the elements of which buildings are composed retain their authentic artistic and historical features, which merit conservation. The specificity of modern materials and means of production only necessitates an updating of the techniques restorers use, without conceptual changes. ${ }^{74}$

For these theorists, modern architecture possesses abstract features, which constitute its fundamental artistic dimensions. These need to be maintained or recovered. It is therefore important to seek to reintegrate the artistic unity of the work, should this have been damaged. This provision, however, encounters resistance from a historical point of view, which may allow the incorporation of changes that negatively affect the building's image, creating the need for a critical valuation. ${ }^{75}$

Although it is acknowledged that, during the era in which modern architecture was constructed, and in the present day, the value of novelty prevails, they indicate the need to also observe the value of antiquity. Maintaining signs of decay depends on a preliminary assessment of historical and artistic values and may occur, provided that it does not involve further deterioration. ${ }^{76}$

They consider that photographs, important instruments for the dissemination of modern architecture, do not provide an understanding of the building's real dimensions, but rather of its ideals. Photographs particularly those of recently concluded buildings can lead to the supposition that an authentic image of the building exists, one that corresponds to the author's intention. These theorists consider this a fallacy. They also point out that photographs stimulate an understanding of the architecture's exterior, rather than its materiality. They understand that the more buildings are studied, the more we understand that
74 CARBONARA, 1997, p. 582 e 588; CARBONARA 2006, p. 24; CARBONARA 2007-2008, p. 12. See: SALVO, 2016, p26, p. 33.

75 CARBONARA, 1997, p. 583. See: SCIASCIA, 2007, p.58.

76 CARBONARA, 1997, p.360. See: SALVO, 2016, p.26. 
77 CARBONARA, 2008, p.147-149. Ver: SALVO, 2016, p.33.

78 CARBONARA, 1997, p.18, p.360361， p.395; CARBONARA，2006, p.22; CARBONARA, 2007-2008, p. 39-41; TORSELLO, 2005, p.28. See: CORNOLDI, 2007, p.263, p.282-283; SALVO, 2016, p. 63, p.102.

79 CARBONARA, 1997, p. 9-10, p.15, p.30-31, p.357, p.360; CARBONARA 2006, p. 22. See: CORNOLDI, 2007, p.261-263; SALVO, 2016, p.102, p.159.

80 CARBONARA, 1997, p15-16, p.27, p.361, p.374, p.381, p.584585; CARBONARA, 2006, p.22. their complexity cannot be reduced to the information contained in photographs. ${ }^{77}$

One needs to consider the possibility of maintaining or extracting the pieces and parts available between the time of construction and the present day. It is possible to determine their destination simply by evaluating their historical and aesthetic merits. When one needs to sacrifice certain building elements or add others, the authors do not admit new additions based on the imitation of forms, materials or techniques from the past. New creations need to be minimal and discreet, but also specialised and up to date. Their fundamental purpose is to enable the transmission of the material that supports the architectural form. In this sense, they consider that the building has a preliminary artistic unity, and that one has to collaborate in order to restore and transmit this, without dispensing with the contemporary creation. ${ }^{78}$

According to guidelines previously set down by $\mathrm{Ce}-$ sare Brandi, the need to examine and recognize artistic, cultural and historical values has been established, in order to outline the need for the selection of the building and the subsequent activities for each case. Recognition of these values must be made for both architecture produced in more remote times and recent architecture, including modern architecture, without any distinction. In this way, from a preliminary selection, it is possible to carry out the priority conservation of the material and/or image associated with it, bearing in mind its interpretation and future fruition. They consider that intentionality must not be based on the authors' ideas, but rather on their works. Carbonara, however, also recognizes that any critical sense is limited and may alter over time. ${ }^{79}$

In terms of the value of use, the theorists consider that changes may or may not be maintained, depending on how much they interfere with an understanding of the historical and artistic values detected in the building. They note that maintenance of or adaptations to functionality and the insertion of new facilities are sometimes necessary, but must be minimal, so as not to interfere with any understanding of the historical and artistic stages. Reuse is considered important for enabling the perpetuation of buildings, but is not the purpose of restoration, not even when addressing modern architecture. However, under certain circumstances, they state that it is also possible to dispense with the need to bestow any practical use on the building. ${ }^{80}$ 
For Carbonara, reconstructions, including of modern architecture, acquire other dimensions, because they highlight pre-existing structures without interfering in their material consistency, shaping useful copies from a didactic and evocative point of view, although these should not be restricted to a limited number of exemplary cases. ${ }^{81}$

Restoration, including of modern architecture, is therefore an activity critically determined on a case by case basis, which intends, in the most intact manner possible, to protect and transmit to the future works with recognized historical, artistic and cultural value. Restoration should therefore simultaneously maintain or recover the detected, authentic values or those considered most relevant. They state that restored buildings should maintain or adapt their uses, with functions appropriate to the pre-existing structure. For these authors, conservation is a necessary, preventative act, but neither absolute conservation, nor repristination are not considered plausible. ${ }^{82}$

\section{Conclusions}

Modern Italian architecture (in its broadest sense) is currently undergoing a process of recognition which, in certain cases, leads to restoration. These are manifest practical applications of the theoretical conflicts seen in recent years. One can witness this in the restoration of buildings during the Fascist period, such as in the restorations of the Post Offices around the country; in the Case del Fascio (Giuseppe Terragni's most recognized work in Como); in the series of buildings made for the Mostra d'Oltremare in Naples; in buildings from the 1950s, such as Gio Ponti's Pirelli project in Milan; and in later buildings, such as the Gallaratese by Aldo Rossi, also in Milan. Although examples of theoretical applications exist, the authors note that the restoration of modern Italian architecture remains highly incipient.

Although there is no consensus about the restoration of modern architecture, the debate in Italy continues to be very prolific, and is able to inspire both theoretical and practical repercussions. ${ }^{83}$
81 CARBONARA, 1997, p.16-17; CARBONARA，2006, p.21; CARBONARA 2008, p. 41; TORSELLO, 2005, p.26-27.

82 CARBONARA, 1997; SALVO, 2016.

83 I would like to thank Professor Andrea Pane for his readings and suggestions for the drafting of this text. 


\section{References}

ANZIVINO, Ciro. Specifità del moderno e aporie della conservazione. In: GUARISCO, G. (org). A-letheia - L'architettura moderna, conoscenza, tutela, conservazione. n.4. Florença: Alinea, 1994. p. 97-100.

ARTIOLI, Alberto. Alcuni recenti restauri di opere dell 'architetto Giuseppe Terragni (19041943) - La casa del Fascio e la Villa de Floricoltere a Como. In: GIMMA, Maria Giuseppina (org). Il restauro dell'architettura moderna. Viterbo: Editora BetaGamma, 1993. p.44-56.

ARTIOLI, Alberto. La Casa del Fascio di Como: necessità operative e scelte metodologiche di alcuni restauri. In: GUARISCO, G. (org). A-letheia - L'architettura moderna, conoscenza, tutela, conservazione. n.4. Florença: Alinea, 1994. p.104-105.

AVETA, Aldo. Architetture Moderne: Riflessione sui metodi e sui criteri del restauro. Confronti - il restauro del moderno. Nápoles, n.1, p.36-41, 2012. DOI: 10.4481/conf023

BARDELLI, Pier. Analisi e progetto per la conservazione dell 'edificio moderno. In: CASCIATO, M; MORANTI, S; PORETTI, S. (Org.) ARCHITETTURA MODERNA IN ITALIA. DOCUMENTAZIONE E CONSERVAZIONE, 1999, Roma. Anais... Roma: EDILSTAMPA, 1999. p.393-399.

BARDELLI, Pier. Conoscenze strategiche per il restauro dell 'architettura moderna. Il caso dell 'Unitè d'habitation di Marsiglia. In: GIMMA, Maria Giuseppina (org). Il restauro dell 'architettura moderna. Viterbo: Editora BetaGamma, 1993. p.125-134.

BELLINI, Amedeo. Antico-nuovo: uno sguardo al futuro. In: FERLENGA, A; VASSALLO, E; SCHELLINO, F. Antico e Nuovo: Architetture e architettura. Veneza, Il Poligrafo, 2004. P. 29-39.

BELLINI, Amedeo. Conservare il moderno: un tradimento? In: GUARISCO, G. (org). A-letheia - L'architettura moderna, conoscenza, tutela, conservazione. n.4. Florença: Alinea, 1994. p. 18-20.

BELLINI, Amedeo. Del restauro alla conservazione: dall'estetica all 'etica. Ananke, Milão, n.19, p. 17-21, set. 1997.

BELLINI, Amedeo. Fotografia e fac-simile. Ananke, Milão, n.53, p. 144-146, jan.2008.

BELFIORE, Pasquale. Due questione da redefinire sul moderno. Confronti - il restauro del moderno. Nápoles, n.1, p.31-33, 2012. DOI: 10.4481/conf022

BORIANI, Maurizio. Obsoleto prima ancora che storico. Conservare II "moderno"? In: BORIANI, Maurizio. (org) La sfida del moderno. L'Architettura del XX secolo tra conservazione e innovazione. Milão: Editora Unicopli, 2003. p.7-17.

BORIANI, Maurizio. Un paradosso per il restauro: gli edifici del Movimento Moderno. In: GUARISCO, G. (org). A-letheia - L'architettura moderna, conoscenza, tutela, conservazione. n.4. Florença: Alinea, 1994. p. 90-92.

BORSI, Franco. Il restauro del moderno: problemi e interrogativi. In: GUARISCO, G. (org). A-letheia - L'architettura moderna, conoscenza, tutela, conservazione. n.4. Florença: Alinea, 1994. p. 6-11.

CANZIANI, Andrea. La reconstruzione del quartiere de Kiefhoel de J.j.oud a Rotterdam. La copia, la materia e I'immagine. In: BORIANI, Maurizio. La sfida del moderno. L'Architettura del XX secolo tra conservazione e innovazione. Milão: Editora Unicopli, 2003. p.101-114. 
CAPOMOLLA, Rinaldo. Il palazzo dele Poste di Adalberto Libera a Roma. Questioni generali e aspetti operativi nel restauro del moderno. In: BORIANI, Maurizio. La sfida del moderno. L'Architettura del XX secolo tra conservazione e innovazione. Milão: Editora Unicopli, 2003. p.179-190.

CARBONARA, Giovanni. Avvicinamento al restauro. Nápoles: Liguori, 1997.

CARBONARA, Giovanni. L'immagine oltre la fotografia. Ananke, Milão, n.53, p. 146-148, jan.2008.

CARBONARA, Giovanni. Il restauro del moderno come problema di metodo. In: Parametro, n.266, ano XXXVI, out./nov. 2006. p.21-25.

CARBONARA, Giovanni. Alcuni temi di restauro per il nuovo secolo. In: CARBONARA, G. (org.) Trattato di restauro architettonico. Turim: UTET, 2007-2008. p.1-47.

CARRERA, Marianna. Una nota sull 'influenza della fotografia nel restauro dell 'architettura moderna. Ananke, Milão, n.53, p. 134-140, jan.2008.

CARUGHI, Ugo. Entrevista concedida a Ana Carolina Bierrenbach. Nápoles, 24 jan. 2017.

CARUGHI, Ugo. Il contemporaneo nell 'idea di tutela. In: CARUGHI, Ugo (org). La tutela dell'architettura contemporanea. Turim: Umberto Allemandi, 2012.

CARUGHI, Ugo. Tutela del contemporaneo in Italia. Confronti - il restauro del moderno. Nápoles, n.1, p. 43-51. DOI: 10.4481/conf024

CASCIATO, M. Modern Architecture is durable: using change to preserve. In: van den Heuvel, et all. (org). THE CHALLENGE OF CHANGE. DEALING WITH THE LEGACY OF THE MODERN MOVEMENT, 10, Delft. Anais..., Delft, IOS Press, 2008, p. xiii-xiv.

CASCIATO, Maristella. Cambiare per conservare. In: PALAZZOTTO, Emanuele (org). CONVEGNO INTERNAZIONALE: IL RESTAURO DEL MODERNO IN ITALIA E IN EUROPA, 11-12, 2007, Palermo. Anais... Palermo, FRANCOANGELI, 2007. p.39-42.

CASCIATO, Maristella. I confine del moderno, un confronto aperto fra limiti e limite. In: CASCIATO, M; MORANTI, S; PORETTI, S. (Org.) ARCHITETTURA MODERNA IN ITALIA. DOCUMENTAZIONE E CONSERVAZIONE, 1999, Roma. Anais... Roma: EDILSTAMPA, 1999. p.27-36.

CASIELLO, Stella; Pane, Andrea; Russo, Valentina. Modernist boroughs: conservation of historical values and urban desing. In: CRISAN, Radica et all. (org). WORKSHOP CONSERVATION/REGENERATION - THE MODERNIST NEIGHBOURHOOD, 2011, Bucareste. Anais... Bucareste, 2011. p.231-249.

CASSIANI, Alberto. Moderno, troppo Moderno. Restauro o conservazione di un passato (troppo) prossimo. In: BORIANI, Maurizio. (org) La sfida del moderno. L'Architettura del $X X$ secolo tra conservazione e innovazione. Milão: Editora Unicopli, 2003. p.19-32.

CIUCCI, Giorgio. Il restauro del Moderno. Confronti - il restauro del moderno. Nápoles, n.1, p.10-21, 2012. Entrevista concedida a Stefanno Gizzi.

CORNOLDI, Adriano.Restauri non conservativi. La ricerca delle regole. In: FERLENGA, A; VASSALLO, E; SCHELLINO, F. Antico e Nuovo: Architetture e architettura. Veneza, II Poligrafo, 2004. p. 261-284.

CRIPPA, Maria Antonietta. Restauro del moderno: fortuna critica, incertezze attuative. In: Territorio, n.62, 2012, p.68-75.

DE JONGE, Wessel. DOCOMOMO strategie varie per la Conservazione dell `Architettura del Movimento Moderno in Europa". In: GIMMA, Maria Giuseppina (org). Il restauro dell 'architettura moderna. Viterbo: Editora BetaGamma, 1993. p.153-162. 
DE JONGE, Wessel. Gli obiettivi di Docomomo International. In: CASCIATO, M; MORANTI, S; PORETTI, S. (Org.) ARCHITETTURA MODERNA IN ITALIA. DOCUMENTAZIONE E CONSERVAZIONE, 1999, Roma. Anais do Primo Convegno Nazionale Docomomo-Italia. Roma: Edilstampa, 1999. p.15-17.

DELL'ERBA, Cristiana. La posizione e il ruolo di DOCOMOMO. In: Parametro, n.266, ano XXXVI, out./nov. 2006. p.32-35.

DELL'ERBA, Cristiana. Monumento vivo e testimonianza storica: due culture a confronto con le sorti del moderno. In: CASCIATO, M; MORANTI, S; PORETTI, S. (Org.) ARCHITETTURA MODERNA IN ITALIA. DOCUMENTAZIONE E CONSERVAZIONE, 1999, Roma. Anais do Primo Convegno Nazionale Docomomo-Italia. Roma: Edilstampa, 1999. p.401-407. DENTI, Giovanni. Machine: um tema nella ricerca del moderno. In: GUARISCO, G. (org). A-letheia - $L$ 'architettura moderna, conoscenza, tutela, conservazione. n.4. Florença: Alinea, 1994. p. 23-24.

DEZZI BARDESCHI, Marco. Il Restauro del Weissenhof di Stoccarda, opera del Movimento Moderno. In: GIMMA, Maria Giuseppina (org). Il restauro dell'architettura moderna. Viterbo: Editora BetaGamma, 1993. p.135-144.

DEZZI BARDESCHI, Marco. L' insostenibile leggerezza dell 'istantanea ed il corpo vivo della fabbrica. Ananke, Milão, n.55, p. 149-151, jan.2008.

DEZZI BARDESCHI, Marco. Per il futuro del moderno: battaglie, sconfitte, proposte. Confronti - il restauro del moderno. Nápoles, n.1, p.92-96, 2012. DOI: 10.4481/conf030 DEZZI BARDESCHI, Marco. Stratificazione, fabbrica, ragione: I' (eterna) avventura del progetto. Ananke, Milão, n.76, p. 114-117, set.2015.

DI CRISTINA, Benedetto. Two or three things I know about conservation of modern architecture. In: RISO, Vicenzo (org). SEMINÁRIO INTERNACIONAL: MODERN BUILDING REUSE: DOCUMENTATION, MAINTENANCE, RECOVERY AND RENEWAL. Guimarães. Anais... Guimarães, mai. 2014. p.13-28.

GIMMA, Maria Giuseppina (org). Il restauro dell'architettura moderna. Viterbo: Editora BetaGamma, 1993.

GIOENI, Laura. Marco Dezzi Bardeschi. Restauro: due punti e da capo. Milão: Franco Angeli, 2004.

GRAVAGNUOLO, Benedetto. Restauro del moderno. Aporie culturali e questioni di metodo. In: Confronti - il restauro del moderno. Nápoles, n.1, p.102-105, 2012. P.25-28. DOI: $10.4481 /$ conf021

LA REGINA, Francesco. L'Architetttura nell'epoca della sua riproducibilità. Appunti sul "restauro del moderno". In: PALAZZOTTO, Emanuele (org). CONVEGNO INTERNAZIONALE: IL RESTAURO DEL MODERNO IN ITALIA E IN EUROPA, 11-12, 2007, Palermo. Anais... Palermo, FRANCOANGELI, 2007, p.67-76.

LOCATELLI, Vittorio (org). Marco Dezzi Bardeschi. Restauro: punto e da capo. Frammenti per uma (impossibili) teoria. Milão: Franco Angeli, 2009. Primeira Edição 1991.

MANGONI, Fabio. Emblemi del Movimento moderno e immagine fotográfica: il restauro "alla Dorian Gray". Confronti - il restauro del moderno. Nápoles, n.1, p.102-105, 2012. DOI: $10.4481 /$ conf031

MARCONI, Paolo. Disegno, no fotografia. Ananke, Milão, n.53, p. 151-153, jan.2008.

MARCONI, Paolo. Materia e significato. La questione del restauro architettonico. Bari/ Roma: Editori Laterza, 1999. 
MARINO, Bianca. Il restauro dopo e durante i "Moderni": um "autentico" valore di novità. Confronti - il restauro del moderno. Nápoles, n.1, p.110-118, 2012. DOI: 10.4481/conf033

MARINO, Bianca. La caverna delle idee. Notazione sull'autentico tra antico e nuovo nel restauro del Novecento. In: FERLENGA, A; VASSALLO, E; SCHELLINO, F. Antico e Nuovo: Architetture e architettura. Veneza, II Poligrafo, 2004. p. 443-458.

MORABITO, Giovanni. Specifità del restauro del moderno: strumenti e metodi di intervento. In: GIMMA, Maria Giuseppina (org). Il restauro dell'architettura moderna. Viterbo: Editora BetaGamma, 1993. p.145-153.

PICONE, Renata. Il Moderno ala "prova del tempo". Restauro e deperibilità delle architetture italiana del XX secolo. Confronti - il restauro del moderno. Nápoles, n.1, p.52-60, 2012. DOI: $10.4481 /$ conf025

PORETTI, Sergio. Il modo di construire: un filo di continuità nell'architettura italiana del Novecento. In: CASCIATO, M; MORANTI, S; PORETTI, S. (Org.) ARCHITETTURA MODERNA IN ITALIA. DOCUMENTAZIONE E CONSERVAZIONE, 1999, Roma. Anais... Roma: EDILSTAMPA, 1999, p.121-128.

PORETTI, Sergio. Premessa. In: CASCIATO, M; MORANTI, S; PORETTI, S. (Org.) ARCHITETTURA MODERNA IN ITALIA. DOCUMENTAZIONE E CONSERVAZIONE, 1999, Roma. Anais do Primo Convegno Nazionale Docomomo-Italia. Roma: Edilstampa, 1999. p.11-12. PORETTI, Sergio. Specificità del restauro del moderno. In: Territorio, n.62, 2012; p; 8894. DOI: $10.3280 /$ TR2012-062017

PORZIO, Pier Luigi. Note sull' azione di salvaguardia e restauro del Moderno a Roma. In: GIMMA, Maria Giuseppina (org). Il restauro dell 'architettura moderna. Viterbo: Editora BetaGamma, 1993. p.57-60.

SALVO, Simona. Il restauro dell 'architettura contemporanea come tema emergente. In: CARBONARA, G. (org). Trattato di restauro architettonico. Turim: UTET, 2007-2008. p.265-316.

SALVO, Simona. Nuovo, vecchio o antico? Applicabilità della teoria del restauro alle opere d'architettura contemporanea. In: CASCIATO, M; MORANTI, S; PORETTI, S. (Org.) ARCHITETTURA MODERNA IN ITALIA. DOCUMENTAZIONE E CONSERVAZIONE, 1999, Roma. Anais do Primo Convegno Nazionale Docomomo-Italia. Roma: EDILSTAMPA, 1999, p.441446.

SALVO, Simona. Restaurare il Novecento. Storia, Esperienze e prospettive in architettura. Macerata: Editora Quodlibet, 2016.

SALVO, Simona. Restauro e "restauri" delle architettura del Novecento: interventi sui gratacieli a confronto. In: FERLENGA, A; VASSALLO, E; SCHELLINO, F. Antico e Nuovo: Architetture e architettura. Veneza, II Poligrafo, 2004. p. 459-471.

SCARROCCHIA, Sandro. Il moderno culto dei monumenti. In: GUARISCO, G. (org). A-letheia - L'architettura moderna, conoscenza, tutela, conservazione. n.4. Florença: Alinea, 1994. p. 25-27.

SCIASCIA, Andrea. Restauro do moderno. Restauro do metodo. In: PALAZZOTTO, Emanuele (org). IL PROGETTO NEL RESTAURO DEL MODERNO, Palermo, Napoli e Régio Calabria. Anais... Palermo, Napoli, Reggio Calabria, 2007, p.53-64.

TORSELLO, Paolo (org). Cos 'è il restauro? Nove studiose a confronto. Veneza: Marsilio, 2005.

TORSELLO, Paolo. Figure di pietra. L'architettura e il restauro. Veneza: Marsilio, 2006. 
TORSELLO, Paolo. L'abitare, non I'immagine. Ananke, Milão, n.53, p. 153-155, jan.2008.

TORSELLO, Paolo. La dialettica restauro/progetto. Ananke, Milão, n.19, p. 29-33, set. 1997.

VITTORINI, Rosalia. Note sulla tutela e la conservazione dell 'architettura italiana del XX secolo. PICONE, Renata. Il Moderno ala "prova del tempo". Restauro e deperibilità della architettura del XX secolo. Confronti - il restauro del moderno. Nápoles, n.1, p.62-70, 2012. DOI: $10.4481 /$ conf026

VITTORINI, Rosalia. Conversazione con Rosalia Vittorini, presidente di DOCOMOMO Italia Onlus. Entrevista concedida a Francesca Rosa. Hevelius 'webzine, ago. 2013. Disponível em: < http://www.hevelius.it/webzine/leggi. php?codice=427>. Acesso em: 02 jan. 2017. 